\title{
Strategi Pengelolaan Citra Pesantren Qiroatussab'ah Kudang Melalui Program Naghmah Quran
}

\author{
Ulfah Wafa Almubarokah*, Khoiruddin Muchtar 1, Abdul Mujib 2 \\ 1Jurusan Ilmu Komunikasi Humas, Fakultas Dakwah dan Komunikasi, UIN Sunan \\ Gunung Djati, Bandung \\ 2Jurusan Bimbingan Konseling Islam, Fakultas Dakwah dan Komunikasi, UIN Sunan \\ Gunung Djati, Bandung \\ *Email : almubarokab052@gmail.com
}

\begin{abstract}
ABSTRAK
Penelitian ini bertujuan untuk mengetahui bagaimana pesantren Kudang mengelola citranya melalui program Naghmah Quran, mulai dari tahap pencarian data situasi sampai tahap evaluasi. Penulis dalam penelitian menggunakan metode deskriptif kualitatif berdasarkan hasil observasi, dokumentasi, dan wawancara mendalam bersama 4 orang informan. Hasil penelitian menunjukkan bahwa strategi pengelolaan citra pesantren Qiroatussab'ah Kudang melalui program Nagmah Quran dilakukan dengan mengelola situasi program Naghmah Quran dengan pengumpulan informasi terkait citra pesantren yang didapat melalui alumni, perencanaan program Nagmah Quran dilaksanakan secara terperinci dengan bantuan analisis SWOT, pelaksanaan program Naghmah Quran dipantau dan diberikan bimbingan sebagai bentuk koordinasi, dan evaluasi program Nagmhah Quran memuat tiga tahapan evaluasi akni evaluasi sebelum pelaksanaan, sedang pelaksanaan, dan setelah pelaksanaan prgram.

Kata Kunci : Pengeolaan Citra, Program
\end{abstract}

\section{ABSTRACT}

This study to find out how the Kudang pesantren manages its image through the Naghmah Quran program, starting from the stage of finding situation data to the evaluation stage. The author in the study used a qualitative descriptive method based on the results of observations, documentation, and in-depth interviews with 4 informants. The results showed that the image management strategy of the Qiroatussab'ah Kudang pesantren through the Nagmah Quran program was carried out by managing the situation of the Naghmah Quran program by collecting information related to the image

Diterima: April 2021. Disetujui: Mei 2021. Dipublikasikan: Juni 2021 
U.W. Almubarokah, K. Muchtar, A. Mujib

of the pesantren obtained through alumni, planning the Nagmah Quran program in detail with the help of SWOT analysis, implementing the Naghmah Quran program monitored and given guidance as a form of coordination, and evaluation of the Nagmhah Quran program contains three stages of evaluation, namely evaluation before implementation, during implementation, and after program implementation.

Keywords : Image Management, Program

\section{PENDAHULUAN}

Pesantren menjadi salah satu lembaga pendidikan yang berfokus pada kaderisasi generasi muda yang identik dengan keislaman. Berdirinya pesantren pada mulanya yakni untuk melakukan perubahan-perubahan yang terjadi di lingkungan masyarakat menuju kehidupan yang lebih baik. Menjadikan manusia sebagai makhluk yang merdeka di atas kemerdekaan yang di Universal.

Pesantren dalam perubahan sosial dimaksudkan untuk menjawab kebutuhan masyarakat terkait perkembangan kehidupan ke arah yang lebih baik yang terbentuk menjadi tiga masa yakni masa lampau masa kini dan masa yang akan datang. Pesantren pada mulanya yakni sebagai Wahana pembinaan keagamaan yang didominasi oleh ajaran kajian Alquran Hadis dan kitab-kitab kuning, tahap selanjutnya Pesantren masa ini menjawab keinginan masyarakat terkait memperkokoh keberadaan Pesantren hingga akhirnya muncul kurikulum pesantren dan pendidikan jalur sekolah mengikuti kurikulum pemerintah, pada tahap terakhir yakni masa depan dimaksudkan bahwa Pesantren ini mampu menjawab tantangan masa depan yang relevan dengan perkembangan ilmu pengetahuan dan tuntutan zaman (Nisa \& Chotimah, 2020:47).

Pesantren Qiroatussab'ah Kudang, atau pesantren Kudang merupakan salah satu pesantren tua di Kabupaten Garut, berdiri sejak 1936 oleh K.H Makmum Bakri yang sampai saat ini pesantren Kudang masih menjadi salah satu pesantren favorit. Pesantren Kudang termasuk pesantren Salaf yang mengkaji ilmu Al-Quran. Pesantren Kudang telah mencetak santri-santri yang berkualitas seperti K.H. Sidiq Mulyana yang merupakan qori internasional Bruney pada tahun 2021, dan H. Salman qori internasional Iran tahun 2019.

Perbedaan penelitian yang dilakukan penulis dengan penelitian lain yakni pada fokus pembahasan serta landasan teoretis ang digunakan. Penelitian terdahulu membahas terkait pesantren Kudang dengan fokus pembahasan terkait peran santri dalam membangun kehidupan masyarakat yang lebih baik. Santri yang menjadi publik internal memiliki karakter yang 
Strategi Pengelolaan Citra Pesantren Qiroatussab'ah Kudang Melalui Program Naghmah Quran dapat mencerminkan pesantren. Santri sebagai siswa mendaoat pendidikan yang kiranya dibutuhkan masyarakat sehingga ketika kembali ia akan berguna bagi lingkungannya. Untuk mencetak santri yang berkualitas maka dalam pembelajarannya perlu adanya komunikasi sosial dan interaksi yang baik (Aprillia, 2019:8).

Penelitian terdahu selanjutnya yakni penelitian strategi pengelolaan reputasi Medion yang sama-sama menggunakan konsep four sep PR pada landasan teoretisnya. Perbedaan penelitainyang dilakukan dengan penulis yakni pada objek penelitian serta teknik pengumpulan data yang digunakan adalah teknik sampling sedangkan pada penelitian ini penulis menggunakan observasi dan wawancara. Hasil penelitian menunjukkan bahwa seorang humas dalam mengelola reputasi harus mengedepankan kepentingan umum dan berkaitan dengan visi perusahaan serta penesuaian media komunikasi sedangkan dalam penelitian ini lebih berfokus pada pengelolaan program sebagai upaya pengelolaan citra lembaga (Wulandari, Fitriawati, \& Sariwaty, 2019:4)

Penelitian yang dilakukan oleh penulis yakni terkait pesantren Kudang dalam mengelola citranyanya selalu mengedepankan kualitas dan esensi dari setiap kegiatan yang dilaksanakan. Pembangunan jalur koordinassi pun diperhatikan secara seksama. Pesantren selalu identik dengan alumni, alumni bagi pesantren diibaratkan sebagai jembatan penghubung antara publik internal dan ekstrenal. Pesantren Kudang dalam keberlangsungannya selalu melibatkan alumni dan ini menjadi salah satu kunci mempertahankan nama baik pesantren di mata publik.

Nama baik ang dimiliki oleh lembaga terbentuk atas etika di masarakat. Citra diwujudkan melalui pemberian informasi yang dikemas secara sederhana untuk dilakukan peninjauan secara seksama dengan tujuan menghindari ketidakpercayaan publik baik internal maupun eksternal terkait kualitas lembaga yang pada akhirnya berpengaruh terhadap eksistensi lembaga (Sadakala, 2020:73).

Pengelolaan nama baik pesantren Kudang ditinjau dari segala aspek, namun salah satu hal yang paling penting yakni beberpa program kegiatan terutama program Naghmah Quran yang dikelola oleh pihak pesantren. Program Naghmah Quran merupakan pembelajaran terkait seni membaca Al-Quran beserta tajwidnya. Ketua yayasan sebagai pimpinan utama melakukann koordinasi bersama perangkat struktur pesantren termasuk dewan kyai dan humas yang menjadi publik internal dan alumni sebagai publik eksternal. Pengelolaan citra pesantren menjadi ha yang unik karena tidak abnyak penelitian pesantren berfokus pada citra sehingga perlu adanya pembahasan terkait pengelolaan citra pesantren Kudang melalui

Reputation: Jurnal Komunikasi dan Penyiaran Islam Vol. 4 No. 2 (2021) 183-204 
program Naghmah Quran.

Berdasarkan latar belakang masalah tersebut dapat dirumuskan beberapa rumusan masalah: bagaimana situasi kegiatan Naghmah Quran sebagai upaya pengelolaan citra pesantren Kudang? Bagaimana perencanaan program Naghmah Quran sebagai upaya pengelolaan citra pesantren Kudang? Bagaimana pererapan program Naghmah Quran sebagai upaya pengelolaan citra pesantren Kudang? Bagaimana evaluasi program Naghmah Quran sebgaia upaya pengelolaan citra pesantren Kudang?

Metode yang digunakan dalam penelitian ini yakni metode deskriptif kualitatif dengan menganalisis hasil dari wawancara. Metode penelitian jika ditinjau secara umum merupakan kegiatan ilmiah yang dilakukan secara bertahap dan saling terhubung tidak bisa melompat pada tahap selanjutnya sebelum tahap yang seharusnya belum dilaksanakan. Secara umum metode penelitian dibagi menjadi tiga langkah yakni menggunakan pertanyaan, pengumpulan data, menganalisis jawaban ang sudah didapatkan (Semiawan, 2010: 2-3).

Metode dekstriptif kualitatif merupakan metode atau cara yang digunakan dalam penelitian yang berbentuk penjabaran atau penggambaran atas hasil- hasil pengumpulan data melalui wawancara secara mendalam. Pada metode deskriptif kualitatif dibutuhkan penentuan informan yang sesuai dengan tema penelitian, karena jawaban dari narasumber menjadi salah satu hal penting dalam penjabaran penelitian.

Wawancara yang dilakukan penulis dalam penelitian dilakukan adalah wawancara semi struktural di mana wawancara dilakukan secara mendalam bersama pihak pesantren Kudang meliputi Ketua Yayasan, Humas pesantren Kudang, dan dua alumni, dengan memberikan pertanyaan berdasarkan susunan yang telah dibuat dan dapat dikembangkan sesuai kebutuhan dan keadaan lapang. Penulis pun dalam penelitian ini melakukan serta observasi lapangan, dan dokumentasi sebagai data tambahan.

\section{LANDASAN TEORITIS}

Penelitian ini menggunakan konsep four step PR dari Cutlip, Center, dan Broom yang dibantu dengan strategi analisis SWOT dari Albert Humphrey. Konsep four step PR menekankan bahwa dalam pengelolaan sebuah citra melalui sebuah program perlu adanya analisa kebutuhan yang selanjutnya data informasi tersebut dirumuskan dalam sebuah 
Strategi Pengelolaan Citra Pesantren Qiroatussab'ah Kudang Melalui Program Naghmah Quran perencanaan, dilaksanakan dengan koordinasi yang baik, agar pada tahap evaluasi program yang dibuat bisa menghasilkan ketercapaian tujuan.

Citra menjadi penting bagi sebuah lembaga maupun perusahaan. citra terbentuk atas persepsi individu yang kemudian menggiring pada opini publik terkait isu atau informasi yang beredar. Pengemasan jalur komunikasi menjadi hal yang penting karena untuk menciptakan opini yang baik peru adanya komunikasi yang baik.

Upaya dalam mengelola citra bukan perkara mudah karena citra harus dibentuk, dipelihara, dijaga, dan diperbaiki keberadaannya. Citra yang baik bisa menjadi negatif hanya dengan satu kesalahan. Sehingga hal ini membuat seorang huas maupun pihak yang pengelola dalam merumuskan suatu kegiatan harus melakukan analisis terkait kemungkinan-kemungkinan yang akan terjadi.

Citra merupakan persepsi publik terhadap lembaga yang muncul melalui proses. Citra perlu dibangun, dipelihara, diperbaiki, dan dijaga keberadaannya. Konsep four step PR dari Cutlip, Center, dan Broom bisa dilakukan untuk mengelola citra karena di dalamnya memuat pembahasan terkait manajemen public relations yang tujuannya yakni citra yang positif, adapun tahapan for step PR meliputi defining public relations problems, planning and programming, taking action and communicating, dan evaluating the program (Cutlip, Center, \& Broom, 2016:320).

Mengetahui citra yang berkembang di publik menjadi tugas bagi seorang humas. Namun dalam praktiknya humas bukan hanya sebuah status atau divisi yang tertera pada lembaga tapi terdapat pula fungsi humas yang dijalankan oleh bidang yang tidak bernamakan humas. Penggalian informasi publik terkait lembaga dilakukan dengan melakukan koordinasi baik antara publik internal maupun eksternal.

Konsep Four Step Public Relations

\section{Defining Public Relations Problems}

Defining public relations problem merupakan pencarian data atau informasi yang dilakukan unuk mengetahui kebutuhan yang harus dipenuhi oleh lembaga agar publik memberikan pandangan lebih terhadap lembaga. Mengetahui permasalahan atau kebutuhan publik baik interna maupun eksternal perlu adanya penggalian informasi (Muchtar \& Aliyudin, 2019:75).

Publik internal dalam rangka pencarian informasi untuk perumusan program berperan sebagai pelaksana atau penggerak kegiatan dengan tujuan memenuhi kbutuhan publik eksternal. Publik internal dalam 
U.W. Almubarokah, K. Muchtar, A. Mujib

lembaga pendidikan pesantren seperti selluruh rangkaian struktur organisasi pesantren, dan para santri pun publik ektsernal meliputi masarakat, pemerintah, alumni, dan tokoh masyarakat lainnya.

Pencarian informasi bagi sebuah lembaga diperlukan agar dalam pelaksanaan kegiatan lembaga tersebut bisa tepat sasaran. Pencarian informasi biasanya timbul karena adanya sebuah permasalahan atau kebutuhan yang harus dilengkapi lembaga. Mengingat terkait pembiayaan dalam sebuah lembaga pun hars diperhatikan. Melalui pencarian informasi baik secara langsung maupun tidak bermanfaat bagi kas lembaga dan tenaga sumber daya manusia sebuah lembaga.

Pencarian informasi akan adanya permasalahan atau kebutuhan yang harus diengkapi bisa melakukan perumusan atau langkah apa yang bisa menjawab permasalahan. Cara untuk mendapatkan jawaban tersebut melalui penyeidikan dan pemantauan opini publik melalui koordinasi yang baik terkait program atau kegiatan yang sekiranya bisa menjawab tantangan (Hayes, Hendrix, \& Kumar, 2007:29-30).

\section{Planning and Programming}

Planning and programming menjadi tahap kedua pada tahapan four step PR. Tahap kedua bisa diakukan dengan menjawab pertanyaan terkait apa yang harus dilakukan dan apa yang harus dikatakan dan mengapa. Perencanaan menjadi sebuah strategi sebelum dilaksanakannya sebuah program atau kegiatan, hal ini dilakukan agar kegiatan tersebut efektif dan efisien (Novianti, Abidin, \& Muchtar, 2020:1).

Tahap perencanaan peru memperhatikan aspek internal dan eksternal. Pihak internal sebagai pelaku utama harus mengetahui apa yang menjadi keunggula, kelemaha sebuah lembaga. Hal ini berguna ketika meakukan koordinasi perumusan kegiatan kita bisa meminimalisir ancaman yang kemungkinan dihadapi oleh lembaga terkait pun agar kegiatan tersebut sesuai dengan keinginan publik eksternal.

Penetapan perencanaan kegiatan bisa dilaksanakan melalui analisis SWOT (strenghths, weaknesses, oppurtuities, thretas) dengan tahapan pembuatan perencanaan seperti pembuatan manajemen strategis dengan menentukan tujuan jangka pendek dan jangka panjang kegiatan, pemberian arahan kepada publik yang bekerja, pemberian pembinaan publik internal, penentuan target peserta atau publik yang dituju, menuliskan tujuan program dengan mengemukakan hasil-hasil yang diinginkan (Mukarom \& Laksana, 2015:198-199)

Pencarian informasi bagi sebuah lembaga diperlukan agar dalam 
Strategi Pengelolaan Citra Pesantren Qiroatussab'ah Kudang Melalui Program Naghmah Quran pelaksanaan kegiatan lembaga tersebut bisa tepat sasaran. Pencarian informasi biasanya timbul karena adanya sebuah permasalahan atau kebutuhan yang harus dilengkapi lembaga. Mengingat terkait pembiayaan dalam sebuah lembaga pun hars diperhatikan. Melalui pencarian informasi baik secara langsung maupun tidak bermanfaat bagi kas lembaga dan tenaga sumber daya manusia sebuah lembaga.

Pencarian informasi digunakan sebagai upaya mengatasi persoalan atau kebutuhan yang perlu dipenuhi. Masalah merupakan sebuah kesenjangan antara apa yang terjadi dengan apa yang diharapkan. Mengetahui permasalahan yang terjadi di sebuah lembaga maupun di sebuah perusahaan ada beberapa langkash yang bisa dilakukan sebagai bentuk pencarian data, salah satunya yakni teknik audit humas (public relations audit) dengan rincian langkah yakni melakukan pendataan segmen antara publik internal dan eksternal atau secara sederhana disebut fase identifikasi pihak- pihak kunci dalam lembaga. Kedua yakni dengan melakukan penegasan sudut pandang publik terkait cara lembaga bergerak melalui kegiatan survei terkait kedekatan lembaga dengan publiknya (Mukarom \& Laksana, 2015: 171-172).

Pencarian informasi terkait kebutuhan publik yang pada akhirnya memiliki pengaruh terhadap nama baik lembaga maka lembaga perlu melihat dua sudut pandang yakni internal dan eksternal. Publik merupakan khalayak atau masyarakat secara umum namun memiliki tujuan yang sama dan ada keterkaitan satu sama lain. Penegasan sudut pandang dalam pencarian informasi kebutuhan perlu dilakukan agar publik internal sebagai penggerak bisa fokus dalam merumuskan perencanaannya dan menentukan tujuan apa yang sebenarnya ingin dicapai.

Pencarian informasi akan adanya permasalahan atau kebutuhan yang harus diengkapi bisa melakukan perumusan atau langkah apa yang bisa menjawab permasalahan. Cara untuk mendapatkan jawaban tersebut melalui penyeidikan dan pemantauan opini publik melalui koordinasi yang baik terkait program atau kegiatan yang sekiranya bisa menjawab tantangan (Hayes, Hendrix, \& Kumar, 2007:29-30)

\section{Taking Actions and Communicating}

Taking actions and communicating menjadi tahap keiga yakni terkait bagaimana publik melaksanakan kegiatan yang telah direncanakan serta bagaimana mengkomunikasikannya baik kepada publik internal maupun eksternal. Kunci dari tahap ketiga yakni selain dari proses perencanaan yang matang juga koordinasi menjadi salah satu hal yang utama.

Optimalisasi sebuah perencanaan perlu memperhatikan beberapa 
langkah seperti penetapan tujuan jangka pendek dan panjang serta melakukan pengarahan pada saat berlangsungnya kegiatan, maka perlu ada bimbingan khusus ketika lembaga melaksanakan kegiatan. Bimbingan mampu memberikan bantuan ketika seseorang mengalami permasalahan baik secara internal maupun eksternal dan ini bisa memperlansar proses kegiatan (Rohamah, Fachrudding, \& Mujib, 2018:42).

Pelaksanaan kegiatan pun tidak akan berjalan jika tidak ada komunikasi yang biak. Komunikasi dalam keberlangsungan hidup manusia menjadi penting. komunikasi bisa memberi jalan juga bisa mematahkan jalan. Pelaksanaan kegiatan tanpa disertai komunikasi yang baik bisa menimbulkan kesalahfahaman, dan ini bisa merusak reputasi.

Pembuatan sebuah kegiatan maupun program tentu memilliki beberapa orang yang terkumpul dalam beberapa bidang. Proses penugasan yang dilakukan tentu memiliki ketua dan penanggungjawab kegiatan atau program. Tugas dari seorang ketua maupun penanggungjwab baik secara keseluruhan maupun perbidang memiliki tanggungjawab mengayomi bawahannya dalam melaksanakan tugasnya.

Pengambilan keputusan saat proses perencanaan kegiatan dengan pengambilan keputusan saat proses kegiatan berlangsung sangat berbeda. Pengambilan keputusan saat kegiatan berlangsung tidak memiliki waktu yang banyak karena itu peru koordinasi secara matang agak intruksi satu arah. Keahlian dalam berkomunikasi pada tahap ini sangat penting karena jika salah mengambil keputusan maka akan berpengaruh terhadap keberlangsungan progrm (Qolbiyah, Amin, \& Astuti, 2018:45).

Pelaksanaan kegiatan yang telah direncanakan perlu adanya persiapan kesiapan sebelum praktik dilaksanakan. Akan selalu adanya pertanyaan terkait kesiapan yang akan dilakukan oleh pihak terkait dengan tugas yang diemban. Hal ini yang membuat pentingnya komunikasi dalam koordinasi untuk melaksanakan kegiatan maupun program yang sebelumya telah direncanakan

\section{Evaluating the Program}

Evaluating the program masuk pada tahap terakhir. Evaluasi program, diartikan sebagai proses sistematis berupa pemberian nilai atas sebuah keberlangsungan program yang telah diputuskan. Tahap evaluasi memiliki tiga langkah yang harus disiapkan yakni penentuan kriteria evaluasi, perbandingan hasil, pengumpulan data dan informasi, dan mengaikan evaluasi dalam bentuk pembelajaran untuk kebijakan kedepannya.

$$
\text { Evaluasi menjadi sebuah tahapan terakhir dalam menjalankan }
$$


Strategi Pengelolaan Citra Pesantren Qiroatussab'ah Kudang Melalui Program Naghmah Quran sebuah kegiatan. Kegiatan evaluasi menjadi penentu apakah program atau kegiatan yang telah dilaksanakan harus dilaksanakan kembali atau justru dihilangkan. Evaluasi dapat menjawab hal-hal yang dipertanyakan terkait perihal yang telah dilakukan (Yulianita, 2007:128).

Evaluasi dilakukan oleh semua pihak sesuai pada bidangnya masingmasing pada saat pelaksanaan sebuah kegiatan maupun program. Kegiatan evaluasi memerlukan pengetahuan terkait perencanaan serta tahapantahapan sebelum kegiatan guna mengetahui tingkat keberhasilan program atau kegiatan.

Evaluasi sebuah program bisa diartikan sebagai bentuk pengumpulan informassi terkait hasil realisasi kegiatan yang telah dilakukan. Peletakkan evaluasi bukan hanya diakhir seluruh tahapan kegiatan tapi mulai dari hasil akhir tahap pertama sampai tahap terakhir, semua dikumpulkan dan dibahas untuk ditinjau terkait kekeliruannya.

Evaluasi program memiliki tahapan bukan hanya satu kali pada setiap program. Evaluasi dilaksanakan mulai dari tahap sebelum kegiatan, ketika pelaksanaan kegiatan, dan setetlah pelaksanaan kegiatan, semua itu peru dievaluasi dan dijadikan catatan. Tahap evaluasi dilakukan sampai terjawabnya seberapa pengaruh yang ditimbulkan oleh kegiatan dan bagaimana dampaknya terhadap citra lembaga (Mukarom \& Laksana, 2015:246-247).

Evaluasi program yang dilakukan secara bertahap mengurangi tingkat kesalahan yang akan dilakukan oleh pihak yang memiliki tugas dalam program atau kegiatan tersebut. Evaluasi yang dilakukan terkait awal pelaksanaan kegiatan memberikan penilaian sejauh mana kesuksesan oerencanaan dan analisa yang dilakukan. evaluasi yang dilakukan saat kegiatan membantu menilai sejauh mana pemahaman pihak yang mendapatkan tugas serta bisa memberikan penilaian terkait apakah koordinasi yang dilakukan sudah tepat atau belum. Evaluasi diakhir yakni evaluasi yang menyangkut tahap awal dan akhir terkait apakah hasil yang diberikan sesuai dengan harapan yang diiginkan oleh publik eksternal

\section{HASIL DAN PEMBAHASAN}

Penelitian ini dilakukan di Limbangan kabupaten Garut. Pesantren Kudang merupakan pesantren salafi yang fokus kajiannya yakni ilmu AlQuran. Pesantren Kudang berdiri sejak 1936 oleh K.H. Makmum Bakri dan termasuk salah satu pesantren tua di Garut. Pengeolaan citra yang dilakukan pesantren melibatkan publik internal dan eksternal. Strategi 
pengelolaan citra pesantren Kudang menggunakan program unggulan yakni Naghmah Quran.

Program Naghma Quran telah ada sejak pesantren ini berdiri, fungsi dari program ini yakni mencetak santri yang berkualitas dan bisa bermanfaat bagi lingkungan. Pengelolaan program Naghmah Quran bisa berdampak pada citra karena produk dari program ini akan disiimpan atau digunakan oleh publik internal dan eksteranl melalui beberapa program lanjutan seperti Muhadhoroh, Musabaqoh Akhirussanah, dan Tutor.

Berdasarkan hasil penelitian pada proses wawancara bersama empat orang informan baik seara langsung maupun daring, serta observasi dan dokumentasi, Pihak pesantrern Kudang dalam mengelola citranya melakukan empat tahapan four step PR pada program Naghmah Quran dengan pembahasan situasi kegiatan Naghmah Quran, perencanaan program Naghmah Quran, pelaksanaan program Naghmah Quran, dan Evaluasi program Naghmah Quran.

Situasi Program Naghmah Quran Sebagai Upaya Pengelolaan Citra Pesantren Kudang

Pertama, Situasi program Naghamh Quran sebagai upaya pengelolaan citra pesantren Kudang memiliki empat komponen yang melekat pada proses pembentukkan citra mulai dari persepsi yang ada pada individu kemudian menjadi sebuah kognisi yang nantinya akan menjadi motivasi dan kemudian menjadi sebuah sikap atau cara pandang individu terkait citra sebuah lembaga yang dibentuk melalui proses sebuah program.

Pesantren memiliki ciri khas tersendiri. Perbedaan pesantren salah satunya terletak pada kajian keilmuan yang diajarakan. Beberapa pesantren dengan metode dulu biasanya menggunakan metode salaf yakni fokus pada penguasaan teks dari pada praktek, sedangkan pesantren modern fokus pada interaksi penggunaan bahasa. Keberadaan pesantren menyesuaikan dengan kebutuhan publiknya karena awal beridinya sebuah pesantren adalah untuk menjawab persoalan masyarakat (Habibi, 2019:2).

Pesantren hadir untuk menjawab keresahan masyarakat dan sekitar terkait generasinya terutama umat muslim. Pesantren memiliki fokus kajian yang beragam menyesuaiakan dengan sanad dan publik eksternal sebagai calon snatri. Menentukan pesantren yang memiliki kaulitas yang baik selain dari kualitas santri sebagai produknya, sanad menjadi hal yang lebih penting. belajar tentang agama perlu memiliki asal-usul yang jelas karena dalam belajar agama jika sedikit melakukan kesalahan akan berakibat fatal terutama bagi publik yang selalu menelan mentah dalam perihal aqidah. 
Strategi Pengelolaan Citra Pesantren Qiroatussab'ah Kudang Melalui Program Naghmah Quran

Pesantren Qiroatussab'ah Kudang emiliki ciri khas dalam tarik saura dan dalam bidang qiroa'at atau cara membaca Al-Quran yang terdiri atas hafes, qolun, wares, dan masih banyak lagi. santri Kudang memiliki tampilan yang khas dalam berpaikaian salah satunya seprti penggunaan jilbab yang mewajibkan santrinya menggenakan jilbab berwarna putih. Baik disadari maupun tidak setiap santri bisa menjadi citra bagi lembaganya baik disengaja maupun tidak, baik dapat dijelaskan maupun tidak dapat dijelaskan tapi pada kenyataannya setiap santri memiliki ciri khas dan bisa menjadi pembeda antara lembaga satu dengan lembaga yang lain.

Mengetahui apa yang menjadi persoalan public relaions peru adanya informasi dari berbagai pihak baik internal maupun eksternal sebelum merumuskan kegiatan. Pengumpulan informasi digunakan untuk menentukan tujuan sampai pada akhirnya mendapat sebuah keputusan. Kegiatan defining public relations problem menjadi langkah dalam mendapatkan gambaran terkait kebutuhan apa yang harus dipenuhi sehingga humas mampu mengetahui situasi sesungguhya terkait dampak atas keberadaan sebuah program (Morissan, 2020:114).

Peantren Kudang dalam mengeoa citra mengawali angkah dngan mencari tahu apa yang sedang dibutuhkan oleh masyarakat pada lembaga. Penulis menemukan bahwa dalam proses pencarian informasi terkait permasalahan atau kebutuhan yang dihadapi masyarakat atau publik eksternal melalui alumni. Dan terkait kebutuhan internal melalui struktur ogranisasi pesantren itu sendiri.

Tahap awal dalam mengelola citra melalui program perlu adanya penentuan permaslaahan bisa didapatkan melalui penelitian dan pengawasan terkait pengetahuan, pendapat publik, serta sikap dan tingkah laku publik yang memiliki kepentingan atau memiliki pengaruh terhadap keberlangsungan lembaga (Permasih, Abidin, \& Ma'arif, 2018:29).

Alumni dalam lembaga pendidikan pesantren menjadi jembatan penghubung antara masyarakat, pemerintah, dengan lembaga. Alumni menjadi representatif pesantren ayng terjun langsung dengan masyarakat. Pesantren Kudang dalam menjawab permasalahan publik sennatiasa melakukan koordinasi bersama alumni, karena itu berdasarkan hasil wawancara dengan ketua yayasan dan alumni, mereka seringkali melakukan koordinasi baik secara daring maupun luring.

Perencanaan Program Naghmah Quran Sebagai Upaya Pengelolaan Citra Pesantren Kudang

Kedua, perencanaan program Naghmah Quran sebagai upaya pengelolaan citra memperkirakan jawaban atas pertanyaan apa yang harus 
dilakukan serta mengapa perlu dilakukan. perencanaan menjadi sebuah langkah yang panjang karena perlu adanya pertimbangan baik dari segi internal maupun eksrenal. Perencanaan yang telah dibangun pun perlu memperhatikan bagaimana cara mensosialisasikan kepada publik terkait alasan pembuatan kegiatan.

Penetapa perencanaan perlu mempertimbangkan beberapa hal seperti apa yang menjadi keunggulan lembaga, apa yang menjadi kekurangan, adakaha kesesuaian kegiatan dengan tujuan lembaga, serta mampukah lembaga mengahdapi kendala yang terjadi dari adanya kegiatan, dan apa keuntungan yang didapat oleh lembaga jika melaksanakan program tersebut. Untuk menjawab hal ini perlu adanya bantuan analisis, salah satunya yakni analisis SWOT yang memuat unsur perumusan sebuah perencanaan agar lebih matang (Fatimah, 2016:7-8).

Pesantren Kudang dalam membuat perencanaan mengimplementasikan tahapan yang ada pada konsep dan analisis yang dipilih penulis. Berdasarkan hasil wawancara dengan pihak internal, pesantren Kudang dalam merancang Naghmah Quran memperhatikan aspek keunggulan para santri, kelemahan santri, serta ancaman dan keuntungan apa yang akan didapatkan lembaga dari pelaksanaan Naghmah Quran baik dalam bentuk opini publik maupun akses pemenuhan kkebutuhan pesantren yang dijamin oleh pemerintahan selaku pihak eksternal.

Perencanaan perlu melakukan pertimbangan sebelum memutuskan. Pertimbangan secara menyeluruh diasosiasikan dalam beberapa langkah yakni berupa pengenalan permasalahan, melakukan definisi terkait masalah, dan diakhiri dengan pemilihan solusi yang sekiranya bisa menjadi alternatif pemecahan permasalahan atau kebutuhan, menurut Anderson solusi alternatif yakni tindakan dari keputusan yang dibuat atau langkah akhir yang mennetukan (Basyaib, 2007:2)

K.H. Atho selaku ketua Yayasan menuturkan bahwa pesantren Kudang dalam merumuskan program selain mempertimbangkan keunggulan dan kekurangan dari santrinya, juga memperhatikan kebijakan pemerintah. Sebagai lembaga pendidikan pesantren harus mengikuti keijakan yang telah ditetapkan demi kemaslahatan bersama karena jika perencanaan memberikan hasil yang negatif maka kepercayaan publik akan berkurang, itulah yang menjadi alsan pesantren Kudang senantiasa mengelola citra pada perencanaan program memperhatikan pendapat dua aspek.

Perencanaan terkait program disusun secara teliti, matang, dan 
Strategi Pengelolaan Citra Pesantren Qiroatussab'ah Kudang Melalui Program Naghmah Quran menyeluruh. Perencanaan memiliki fungsi sebagai pedoman dalam pelaksanaan kegiatan. Sebelum melaksanakan program perlu adanya pedoman pelaksanaan program dan perencanaan bisa menjadi kunci kesuksesan sebuah acara. Perencanaan membutuhkan penyusunan yang sistematis dan menyeluruh berdasarkan data-data yang diperoleh melalui pengamatan lingkungan (Qolbiyah, Amin, \& Astuti, 2018:45).

Pesantren Kudang dalam mengambil keputusan pada sebuah perencanaan selalu mempertimbangkan berbagai aspek. Aspek yang dapat mempengaruhi pesantren yakni aspek internal meliputi pemilik pesantren (keluarga pesantren), para pengurus santri dalam lingkup struktur organisasi, serta para santri. Aspek eksternal atau publik eksternal yang dapat mempengaruhi keberlangsungan pesantren meliputi masyrakat, alumni, dan pemerintahan. Namun pada aspek eksternal sebuah lembaga pendidikan pesantren biasanya diwakilkan oleh para alumni sebagai jembatan antara kedua aspek.

Perencanaan yang dibuat oleh pesantren perlu adanya keputusan dewan pimpinan dan ketua yayasan. Adapun santri sebagai bagian dari struktur organisasi hanya menjadi pelaksana dari keputusan yang telah ditetapkan oleh pimpinan sekaligus sebagai pengawas keberjalanan kebijakan dan alumni dalam pengambilan keputusan sebagai sumber referensi kebijakan yang dirapatkan oleh public internal pesantren.

Sikap hati-hati yang dilakukan oleh pesantren Kudang terkait kebijakan salah satunya dengan selalu berusaha untuk bersikap netral. Pasalnya terkadang dalam sebuah lembaga khususnya pesantren biasanya digunakan sebagai alat pencitraan bagi beberapa kaum elit, terutama dalam menjelang pemilihan. Mengingat keberpihakan lembaga pendidikan sangat berpengaruh besar di masyarakat, maka pondok pesantren dalam merumuskan kebijakan pada sebuah program mempertimbangkan berbagai aspek dan penetapa sebuah keputusan diputuskan secara matang melalui pandangan masyarakat dan pandangan internal, begitupun dengan program Naghmah Quran.

Program Naghmah Quran merupakan salah satu program unggulan yang direncanakan sejak berdirinya pesantren tersebut. Program Naghmah Quran menjadi penting karena dari program ini akan menghasilkan nama baik lembaga. Program Naghmah Quran dalam perencanaannya memiliki tujuan jangka pendek dan jangka panjang, serta dalam pelaksanaannya pun memperhatikan aspek pendukung baik internal maupun eksternal yang dapat mempengaruhi keberlangsungan program baik secara langsung maupun tidak. 
Hasil dari koordinasi ketua yayasan dengan alumni kemudian dirumuskan dan dibahas kedalam rapat internal pengurus pesantren yang kemudian dikaji bersama terkait hal-hal apa saja yang harus dirumuskan dan dimasukkan dalam pelaksanaan program agar adanya kesesuaian antara informasi yang didapat dengan pelaksanaan yang akan dilakukan pesantren.

Penerapan Program Naghmah Quran Sebagai Upaya Pengelolaan Citra Pesantren Kudang

Ketiga, penerapan program Naghmah Quran sebagai upaya pengelolaan citra pesantren Kudang dilakukan dengan cara memberikan pelatihan secara maksimal terhadap santri sebagai produk pesantren. Jika pada sebuah perusahaan produk merupakan benda atau hasil yang dikelurkan oleh perusahaan, maka dalam lembaga pendidikan pesantren yang dimaskud dengan produk yakni santri-santri, karena santri ini yang nantinya akan dirasakan manfaat keberadaannya oleh masyarakat.

Program nama Quran menjadi salah satu program yang dapat mewujudkan harapan masyarakat maupun publik eksternal lainnya karena pelaksanaannya bukan hanya sebatas pelaksanaan biasa tetapi terdapat pembimbingan santri sebagai produk unggulan pesantren. Program Naghmah Quran sendiri merupakan program pelatihan secara langsung dari Assatin kepada para santri.

Program Naghmah Quran keberadaannya sudah ada sejak pesantren tersebut berdiri. Pesantren Qiroatussab'ah Kudang memang berfokus pada Ilmu Al-Quran yakni pada cara membaca Quran namun disamping itu juga berfkus pada seni membaca Quran. Banyak pengaruh dari adanya pengolahan seni membaca Quran. Banyak orang yang tertarik mempelajari islam usai mendengar lantunan ayat suci $\mathrm{Al}$-quran oleh karena itu seni membaca Al-Quran menjadi penting dan dirumuskan dalam program Naghmah Quran.

Pemberian bimbingan merupakan pemberian bantuan kepada seorang yang tengah menghadapi permasalahan baik internal maupun eksternal. Bimbingan pada seseorang dijadikan sebagai jalan untuk menindaklanjuti arah kehidupan agar sesuai dengan yang dicita-citakan. Pemberian diding andika dilakukan dengan berbagai cara yang tentunya telah disesuaikan dengan kebutuhan publik internal maupun eksternal (Rohanah, Fachruddin, \& Mujib, 2018:42).

Program Nagmah Quran sebagai bentuk upaya pengolahan citra berusaha menghasilkan santri yang berkualitas terutama dalam bidang ilmu 
Strategi Pengelolaan Citra Pesantren Qiroatussab'ah Kudang Melalui Program Naghmah Quran Al-Quran sesuai dengan fokus kajian pesantren. Berdasarkan konsep four step PR pada tahap ketiga dalam pengelolaan Citra yakni melaksanakan kegiatan dan melakukan komunikasi terkait kegiatan dengan menjawab pertanyaan how and when do and say it. Pelaksanaan kegiatan yang dilakukan oleh pesantren Kudang disesuaikan dengan perencanaan yang telah dibuat.

Pelaksanaan program Naghmah Quran selain pemberian bimbingan dalam bentuk pelatihan juga terdapat interaksi yang baik. Pengimplementasian seni membaca Al-Quran harus dilakukan oleh orangorang yang memiliki kompetensi di dalamnya sehingga pihak pesantren harus mencari pengajar dengan kualitas unggul. pesantren Kudang dalam mencari pengajar menggunakan alumni sebagai jembatan.

Kegiatan pelaksanaan kegiatan memerlukan koordinassi yang baik. Implementasi atas tindakan ang berbentuk komunikasi dapat dilakukan dengan cara persuasif maupun informatif. Pada peaksanaan informatif dan persuasif seorang humas mampu melakukan komunikasi secara berulang agar publik memahami pesan yang dimaskud, serta bisa menggunakan media sebagai sarana komunikasi yang tentunya disesuaikan dengan kebiasaan publik (Raturahmi, Dewi, \& Melsani, 2020:33).

Komunikasi yang dilakukan pesantren dengan alumni dikemas secara baik, karena itu dibentuklah sebuah perkumpulan alumni yang kerap kali mengadakan rapat setiap akan melaksanakan Haul atau pengajian bersama memperingatai hari raya besar islam. Kegiatan tersebut biasanya diisi dengan kegiatan makan bersama maupun berbincang santai terkait progres pesantren baik terkait bangunan maupun kualitas pengajar dan santri saat ini.

Alumni dalam pesantren menjadi hal yang utama karena menjadi jembatan koordinasi antara publik internal dan eksternal. Alumni akan memberikan informasi terkait apa saja yang sedang terjadi di masyrakat terkait nama baik pesantren yang kemudian oleh pihak lembaga pesantren data diolah dan diaplikasikan dalam program. Alumni di pesantren Qiroatussab'ah Kudang pun kerap kali dilibatkan dalam pelaksanaan program seperti menjadi pengajar, maupun memberikan motivasi dan bantuan dana untuk infrastruktur pesantren.

Pelaksanaan kegiatan dalam pengelolaan sebuah citra harus direncanakan dan dikomunikasikan dengan baik.tapan pelaksanaan kegiatan menjadi penentu sejauh mana bentuk kerjasama lemabga yang terjalin baik dengan publik internal maupun dengan publik eksternal. Tahap pelaksanaan kegiatan pun nantinya akan mempengaruhi tahapan evaluasi, sebagai penilaian apakah program harus terus berlangsung atau 
dicukupkan, dan apa yang sekiranya perlu ditambah atau dikurangi (Rahmawati \& Anwar, 2017: 12-13)

Komunikasi yang dilakukan pesantren dengan alumni dikemas secara baik, karena itu dibentuklah sebuah perkumpulan alumni yang kerap kali mengadakan rapat setiap akan melaksanakan Haul atau pengajian bersama memperingatai hari raya besar islam. Kegiatan tersebut biasanya diisi dengan kegiatan makan bersama maupun berbincang santai terkait progres pesantren baik terkait bangunan maupun kualitas pengajar dan santri saat ini.

Kegiatan pelaksanaan program Nagmah Quran meliputi pengawasan dalam beberapa hal seperti pengawasan terkait apakah guru sebagai pengajar sudah di tempat, apakah para santri sudah berkumpul di madrasah, dan bagaimanakah perjalanan kegiatan apakah terdapat permasalahan terutama dalam media komunikasinya seperti alat tulis, sound sistem, penerangan tempat pelaksanaan kegiatan, dan masih banyak lagi.

Program Naghmah Quran menjadi salah satu program yang paling disorot karena produk atau output dari program ini mempengaruhi program-program lain di pesantren Kudang. Pelaksanaan program Naghmah Quran pun mendapat perhatian langsung dari para Assatin atau para pengajar yang secara langsung diberi komando oleh para dewan kyai sehingga keberhasilan dan kegagalan program ini menjadi salah satu kunci yang sangat penting dalam mengelola citra pesantren Kudang. Citra.

Evaluasi Program Naghmah Quran Sebagai Upaya Pengelolaan

Keempat, evaluasi program Nagmah Quran sebagai upaya pengolahan citra pesantren Kudang dimaksudkan untuk mengukur sejauh mana kesuksesan program ini berlangsung. Tahap evaluasi menjadi tahap terakhir pada konsep four step PR. Tahap evaluating the program merupakan tahap penentu kesesaian harapan dan kenyataan dari rangkaian yang telah direncanakan. Untuk mengukur kesuksesan program bisa dengan menjawab pertanyaan how we did. Pada tahap evaluasi sering juga dijadikan sebagai penentu apakah program yang telah dirancang harus dilanjutkan atau tidak.

Pelaksanaan evaluasi sebuah program bisa dilakukan dengan beberapa metode, pertama yakni evaluasi persiapan, kedua evaluasi implementasi, dan ketiga evaluasi dampak. Evaluasi persiapan mencakup evaluasi tahap pertama yakni pencarian data atau informassi terkait permasalahan atau kebutuhan publik yang harus dipenuh serta tahapan 
Strategi Pengelolaan Citra Pesantren Qiroatussab'ah Kudang Melalui Program Naghmah Quran perencanaan pembuatan programi. Evaluasi implementasi yakni evauasi terkait kesesuaian antara perencanaan dengan pelaksanaan ketika pelaksanaan kegiatan. Evaluasi dampak yakni evaluasi akhri sebagai bentuk jawaban untuk tahap pertama pada konsep four step PR yakni pencarian informasi terkait lembaga. (Mukarom \& Laksana, 2015:246-247).

Tahap evaluasi dilaksanakan di akhir namun sifatnya menyeluruh mulai dari tahap analisis lingkungan atau tahap analisis situasi, tahap perencanaan, tahap pelaksanaan kegiatan, hingga tahap evaluasi itu sendiri. Kegiatan evaluasi memiliki pengaruh terhadap kepercayaan publik karena hasil dari evaluasi lembaga bisa melihat sejauh mana efektivitas program kegiatan

Nagmah Quran sebagai salah satu program unggulan memiliki beberapa tahapan evaluasi. Berdasarkan hasil wawancara bersama humas pesantren Kudang menuturkan bahwa pada program Naghmah Quran terdapat tiga bentuk evaluasi sesuai dengan tahapan evaluasi yang penulis pilih. Evaluasi setiap tahapan terdapan evaluasi jangka pendek, jangka menengah, dan jangka panjang. Bentuk kegiatan evaluasi yang dilakukan pesantren Kudang yakni dengan beberapa kegiatan seperti kegiatan perlombaan maupun kegiatan ujian.

Ketua yayasan pesantren Kudang menuturkan bahwa tahapan evaluasi pesantren Kudangg dimulai saat pembukaan calon peserta didik. Sebelum para santri belajar di pesantren Kudang pihak pesantren membuat seleksi dalam bentuk tes para calon santri. Tes ini dilakukan sebagai bentuk evaluasi dengan tujuan untuk mendapatkan informasi sejauh kemampuan santri untuk mengikuti pembelajaran, dan sejauhmana pihak pesantren harus memberikan pembelajaran kepada santrinya. Hasil dari evaluasi penerimaan calon santri nantinya akan ditindaklanjuti dalam bentuk penempatan kelas.

Bagi santri yang memiliki suara dan tajwid yang sudah baik maka pelaksanaan program Naghmah Quran biasanya diberikan pelatihan khsusus yakni pelatihan tambahan setelah selesai program Naghmah Quran. Hal ini menjadi salah satu bagian dari bentuk tahap evaluasi jangka pendek pada pesantren Kudang di bidang kajian ilmu Al-Quran yakni dalam bentuk uji kelayakan santri atau ujian tengah semester. Hasil dari evaluasi ini nantinya akan disimpan di raport masing-masing.

Tahap evaluasi kedua yang dilakukan oleh pesantren pada program Naghmah Quran dalam bentuk kegiatan pberbagai perlombaan internal. Kegiatan perlombaan ini melibatkan seleuruh elemen internal pesantren Kudang. Penilaian kesuksesan program Naghmah Quran dilakukan setiap 
minggunya secara bergilir di lingkungan santri. Secara sederhana bentuk evaluasi jangka menengah di pesantren Kudang pada program Naghmah Quran dilakukan dengan program Mubadhoroh. Kegiatan Muhadhoroh merupakan kegiatan perlombaan yang dilakukan oleh santri antar kamar atau kobong. Adapun kegiatan selanjutnya yakni Musabaqah Akbirusanah yakni tahap evaluasi yang dilaksanakan seperti Mubadhoroh namun jangkauannya lebih luas yakni menyangkut seluruh santri yang kemudian dibagi menjadi 3 kelompok sesuai dengan daerah masing-masing.

Evaluasi terakhir yakni evaluasi yang pada praktiknya berkaitan langsung dengan publik eksternal. Evaluasi terakhir ini dapat mengukur sejauh mana efektivitas program Nagmah Quran yang diselenggarakan oleh lembaga terhadap nama baiknya di mata publik. Naghmah Quran menjadi salah satu inti program pesantren yang outputnya diaplikasikan di berbagai aktivitas santri.

Evaluasi akhir dari program Naghmah Quran salah satunya yakni pada program Tutor dan program Musabaqah Tilawatil Quran (MTQ) baik tingkat regional, nasional, maupun internasional. Tahap evaluasi program Naghmah Quran pada program Tutor dilaksanakan sebagai salah satu bentuk dari fungsi humas yakni pembinaan hubungan dengan publik eksternal. Gamabaran terkait program Tutor yakni santri yang telah melaksanakan pendidikan di pesantren selama tiga tahun akan ditempatkan di masyarakat yang membutuhkan pengajar yang berasal dari pesantren Kudang. Pengiriman santrinya pun telah melalui seleksi berdasarkan kesehariannya dalam mengikuti program Naghmah Quran sehingga santri tersebut harus memiliki kompetensi dibidang Ilmu Al-Quran.

Melihat sejauh mana efektivitas program kegiatan dan pengukuran pada program Tutor yakni dilihat pada tahun selanjutnya, apakah pihak masyarakat atau publik yang meminta pengajar kemarin meminta kembali santri yang ditunjuk atau tidak, jika pihak masyarakat meminta kembali maka program Nagmah Quran bagi santri tersebut berhasil, namun jika tidak maka akan dilakukan pelatihan kembali pada santri tersebut terkait pembelajaran di program Nagmah Quran.

Program Naghmah Quran diharapkan bisa menghasilkan santrisantri yang berkualitas dan bermanfaat baik bagi individu maupun bagi masyarakat atau lingkungan sekitar. Akhir dari program Naghmah Quran ialah pandangan publik terkait kualitas santri. Santri sebagai produk dari pesantren harus sesuai dengan tujuan dari pelaksanaan Naghmah Quran sendiri yakni santri-santri yang berkompeten dalam dunia seni membaca Al-Quran. 
Strategi Pengelolaan Citra Pesantren Qiroatussab'ah Kudang Melalui Program Naghmah Quran

Menarik garis akhir dari pentingnya program Naghmah Quran maka program tersebut dirasa membantu pesantren Kudang dalam mengelola citranya. Pembuktian akan kualitas santri melalui program Naghmah Quran menjadi suatu bentuk pengelolaan kualitas yang berjangka dan sistematis. Hasil dari program Naghmah Quran pun selain meningkatkan kualitas santri baik secara langsung maupun tidak langsung mempengaruhi pandangan publik eksternal terkait efektivitas sistem pembelajaran di lembaga.

Program Nagmah Quran bisa menjadi salah satu program yang sukses mengelola citranya karena selain dari perencanaan yang jelas mulai dari tujuan jangka pendek hingga jangka panjang, serta pada saat berlangsungnya kegiatan terjadi koordinasi yang baik antara pihak internal dan eksternal. Program Nagmah Quran pun dalam perencanaannya memperhatikan aspek-aspek yang dapat mempengaruhi keberlangsungan lembaga dan hal ini menjadi nilai tambah akan pentingnya program Naghmah Quran dalam mengelola citra pesantren Kudang

\section{PENUTUP}

Berdasarkan hasil penelitian yang telah dilakukan penulis ditemukan bahwa pihak pesantren Kudang dalam pengelolaan citra pesantren Kudang melalui program Naghmah Quran menjadi langkah yang baik karena pada pengelolaan tersebut memperhatikan hal-hal yang menjadi fokus kajian bersama serta dalam tahap pengelolaan citra melalui program, sama dengan tahapan yang ada pada konsep yang penulis pilih. Atas fokus kajian citra pesantren qiroatussab'ah Kudang melalui program Naghmah Quran ada beberapa simpulan yang dapat penulis ambil dari hasil penelitian diantaranya sebagai berikut:

Situasi kegiatan program Naghmah Quran sebagai upaya pengolahan citra pesantren Kudang rupanya masih berfungsi. Situasi citra yang dialami oleh pesantren saat ini masih dalam keadaan baik. Terkait bagaimana cara pesantren untuk situasi lembaga di mata publik yakni melalui alumni sebagai pihak eksternal yang langsung bersentuhan dengan khalayak, pun hal ini sesuai dengan tahap pertama pada pengelolaan citra yakni defining public relations problem.

Perencanaan program Naghmah Quran sebagai upaya pengolahan citra pesantren Kudang rupanya memperhatikan aspek-aspek yang termuat dalam analisis SWOT serta pada pelaksanaan ini memiliki perencanaan yang baik karena sesuai dengan langkah kedua dalam mengelola sebuah citra yakni planning and programming. 
Penerapan program Naghmah Quran sebagai upaya pengolahan citra pesantren Kudang rupanya memiliki peran yang penting. Program Naghmah Quran dalam pelaksanaannya dipantau secara khusus mulai dari ketua yayasan sampai dewan kyai yang dikoordinasikan oleh para Assatin dan santri yang menjadi pengurus pesantren. Bentuk koordinasi yang dilakukan pada program ini pun baik dan hal ini sesuai dengan tahap ketiga pada pengolahan citra yakni taking action and communicating.

Evaluasi program Naghmah Quran sebagai upaya pengelolaan citra pesantren Kudang rupanya mendapat perhatian khusus. Hal ini terbukti dengan adanya beberapa program lanjutan sebagai tindak evaluasi program Naghmah Quran. Adapun beberapa contoh kegiatan evaluasi yang dilakukan yakni melalui program Tutor, Musabaqam dan Muhadhoroh. Program tersebut nantinya akan membentuk opini publik yang dijembatani oleh para alumni. Hal ini sesuai dengan tahap keempat pada pengolahan citra yakni evaluating the program.

Berdasarkan hasil penelitian yang dilakukan maka secara garis besar bahwa pihak pesantren dalam pengelolaan citra pesantren Kudang melalui program Naghmah Quran telah sesuai dengan konsep yang penulis pilih yakni four step PR dari Cutlip, Center, dan Broom yang memuat tahapan defining public relations problem, planning and programming, taking actions and communicating, serta evaluating the program. Hasil dari data evaluasi kegiatan menunjukkan bahwa program Naghmah Quran selalu memperhitungkan segala aspek yang bisa mempengaruhinya, karena itu pemilihan program Naghmah Quran sebagai salah satu program unggulan pesantren dirasa tepat untuk mempertahankan eksistensi pesantren dari dulu hingga sekarang.

\section{DAFTAR PUSTAKA}

Aprillia, W. K. (2019). Peran Santri dalam Pelestarian Lingkungan Pondok Pesantren Qiroatussab'ah Al Quran Kudang. Digital Library UIN Sunan Gunung Djati, 8.

Basyaib, Fachmi. (2017). Teori Pembuatan Keputusan. Jakarta: Grasindo.

Cutlip, S. M., Center, A.H., \& Broom, G. M. (2016). Effective Public Relations. Jakarta: Prenadamedia Grup.

Fatimah, F. N. (2016). Teknik Analisis SWOT. Yogyakarta: Quadrant.

Habibi, B. . (2019). Integrasi Kurikulum Bahasa Arab Pesantren Tradisional dan Modern di Madrasah Aliah Program Keagamaan. Jounal Imla, 4(2), 2.

Morissan. (2010). Manajemen Public Relations. Jakarta:Prenada Media Group. Muchtar, K., \& Aliyudin. (2019). Public Relations Politik Partai Keadilan 
Strategi Pengelolaan Citra Pesantren Qiroatussab'ah Kudang Melalui Program Naghmah Quran

Sejahtera dalam Pemilukada Jawa Barat. Jumal Communicatus, 3(1), 75.

Mukarom, Z., \& Laksana, M. W. (2015). Manajemen Public Relations. Bandung: CV Pustaka Setia.

Nisa, K., \& Chotimah, C. (2020). Perkembangan Kurikulum Pondok Pesantren. Inovatif, 6(1), 47.

Novianti, S., Abidin, Y. Z., \& Muchtar, K. (2020). Strategi Huma Badan

Narkotika Nasional Jawa Barat dalam Mensosialisasikan Program

Rehabilitasi. Jurnal Inter Act, 9(2), 1.

Permasih, I., Abidin, Y. Z., \& Ma'arif, A. A. (2018). Pengelolaan Media

Sosial Instagram Humas Pemerintah Provinsi Jawa Barat. Jurnal Reputation, 3(1), 29.

Qolbiyah, S., Amin, D. E., \& Astuti, D. R. (2018). Pengelolaan Pemeliharaan Citra Melalui Pameran. Jurnal Reputation, 4(3), 45.

Rahmawati, B. F. \& Amar, S. (2007). Evaluasi Pembelajaran Sejarah.Lombok Timur:Universitas Hamzan Wadi Press

Raturahmi, L., Dewi, R. U., Melsani, S. (2020) Strategi Komunikasi PT.

Pos Indonesia dalam Meningkatkan Reputasi Perusahaan. Jurnal

Digital Media \& Relationshop, 3(1), 33.

Rohamah, M. N., Fachruddin, T., \& Mujib, A. (2018). Peran Bimbingan

Keagamaan pada Remaja untuk Mengurangi Dampak

Penyalahgunaan NAPZA. Jurnal Irsyad, 6(1), 42.

Sadyakala, M. C. (2020). Peran Public Relations dalam Meningkatkan Citra Lembaga Pendidikan. At-Tadbir, 30(2), 73

Wulandari, T., Fitriawati, D., Sariwaty, Y. (2019) Pendidikan dan Pelatihan Sebagai Strategi Public Relations dalam Mengelola Reputasi Medion. Jurnal Digital Media \& Relationship, 1(1), 39.

Yulianita, N. (2007). Dasar-dasar Public Relations.Bandung: LPPM UNISBA 
U.W. Almubarokah, K. Muchtar, A. Mujib 